\title{
Effect of resistive load on the performance of an organic Rankine cycle with a scroll expander
}

\author{
Jie Zhu ${ }^{1 *}$, Ziwei Chen ${ }^{1}$, Hulin Huang ${ }^{2}$ and Yuying Yan ${ }^{1}$ \\ 1 Department of Architecture and Built Environment, the University of Nottingham, \\ University Park, Nottingham, NG7, 2RD, UK \\ 2 College of Astronautics, Nanjing University of Aeronautics and Astronautics, Nanjing, \\ 21016, China \\ * Corresponding author. \\ E-mail address: jie.zhu@ @ottingham.ac.uk
}

\begin{abstract}
An experimental investigation is performed for an organic Rankine cycle system with different electrical resistive loads. The test rig is set up with a small scroll expander-generator unit, a boiler and a magnetically coupled pump. R134a is used as the working fluid in the system. The experimental results reveal that the resistive load coupled to the scroll expandergenerator unit affects the expander performance and power output characteristics. It is found that an optimum pressure ratio exists for the maximum power output. The optimal pressure ratio of the expander decreases markedly as the resistive load gets higher. The optimum pressure ratio of the scroll expander is 3.6 at a rotation speed of $3450 \mathrm{r} / \mathrm{min}$ for a resistive load of $18.6 \Omega$. The maximum electrical power output is $564.5 \mathrm{~W}$ and corresponding isentropic and volumetric efficiencies are $78 \%$ and $83 \%$ respectively.
\end{abstract}

KEY WORDS: Resistive load; Organic Rankine cycle; Scroll expander; Optimal pressure ratio; Electrical power output. 


\section{Introduction}

The interests in low-grade heat sources, which are abundantly available in renewable energy sources, grew dramatically with the awareness of greenhouse effect. A number of novel solutions have been proposed to generate electricity from the low-grade heat. Organic Rankine cycle (ORC) has been paid much more attention in recent years as a very promising technology for energy conversion with the low boiling temperature working fluid (e.g. refrigerants) [1]. Generally, the available low-grade heat sources utilized by the ORC systems include geothermal energy, solar energy, biomass combustion, exhaust gases of gas turbine, and waste heat from power plant [2]. Unlike traditional power cycles, ORC can be applied to small-scale power generation with high flexibility and low maintenance requirements [3]. ORC can be used as a prime mover or integrated with another mover for the combined heat and power generation system. Power generation plants integrating with ORC systems are beneficial to energy consumption and greenhouse gases emissions.

The selection of organic working fluids is of vital importance to the ORC system. An organic fluid is usually characterized by a saturated vapour line with positive slope in the Temperature-Entropy $(T-s)$ diagram which guarantees the working fluid is still at the superheated vapour state in the expansion process [4]. Many research works have been carried out to select the most suitable working fluid for the ORC system. Badr et al. [5] investigated thermodynamic and thermophysical properties of organic working fluids for the ORC system. Saleh et al. [6] concluded that the fluids with relatively low critical temperature are preferred for the system. Li [7] systematically investigated 14 ORC working fluids under various heat source levels, i.e. the various application domains. This paper performed a comprehensive study for both energy and exergy performance under different operating conditions and various ORC system configurations, such as reheat, regenerative ORC and 
ORC with internal heat exchanger. Instead of adopting only one working fluid for an ORC system, a mixture of several different working fluids has been accepted in recent years. Aghahosseini et al. [8] conducted a theoretical study of six types of pure and zeotropic mixture refrigerants: R123, R245fa, R600, R134a, R407c and R404a in an ORC system with low-temperature heat source, and found the mixed working fluids are more suitable for the system due to the nonisothermal phase change. Based on the simulation results, Declaye et al. [9] concluded R134a is a good choice for an ORC system with a smaller size expander. Additionally, Tchanche et al. [10] considered that R134a is the most suitable working fluid for small-scale solar applications in terms of thermodynamic and environmental properties.

The selection of expansion devices for an ORC system depends on the operating condition and the size of the system. Qiu et al. [11] evaluated several expansion devices for micro-CHP ORC systems including turbine, scroll, screw and vane expanders, and suggested that both scroll and vane expanders are suitable for micro-scale ORC systems with capacity ranging from $1 \mathrm{~kW}$ to $10 \mathrm{~kW}$. Ali Tarique et al. [12] stated that a scroll expander is the best choice for small capacities due to the more flexible operation characteristic. As a scroll expander is a positive displacement machine with a fixed expansion ratio, a high efficiency could be achieved at a specific pressure ratio [13]. Scroll expander is considered to be more reliable with less number of moving parts, no inlet and outlet valves [14]. Though various studies on the scroll-based ORC system have been carried out through modelling and experimental investigations, there are few researches on the system operating characteristics. Wang et al. [15] carried out ORC system experimental test and found the isentropic efficiency of scroll expander is in the range of $70 \%$ to $84 \%$. Harada [16] found an isentropic efficiency is over $70 \%$ for a $1 \mathrm{~kW}_{\mathrm{e}}$ scroll expander using R134a and R245a as working fluids. Zhang et al. [17] presented a theoretical model for low-grade heat-driven Rankine cycle with a scroll expander 
and showed a thermal efficiency of $11 \%$. Hogerwaard et al. [18] concluded that the minimum superheating leads to high ORC efficiency and expander isentropic efficiency. Declaye et al. [19] presented the experimental study of scroll-based ORC with R245fa, and found that the isentropic efficiency of the expander degrades faster at lower pressure ratio and high rotation speed. Antonio Giuffrida [20] simulated the performance of an ORC system with a small scroll expander on the basis of a semi-empirical model, and concluded that the expander efficiency is the most sensitive parameter in a low-temperature ORC system. Clemente et al. [21] developed a one-dimensional model of a scroll expander in an ORC cogeneration system and found that there is an optimum expansion ratio maximizing the ORC efficiency, but the influences of electrical load and rotation speed of the expander are not considered. To improve the performance of ORC system, various configurations are proposed, such as the regenerative cycle. Mago et al. [22] compared a regenerative ORC with the basic ORC, and found that regenerative ORC achieves higher efficiency with a lower irreversibility. As for the ORC electrical power output characteristics, there is limited research on the effects of electrical load connected to the ORC system. Pan et al. [23] carried out experimental research on the performance of a scroll expander in ORC system with working fluid R123, and remarked that the electrical loads affect rotation speed, isentropic and mechanical efficiencies of scroll expander, and the power output from the generator. Wu et al. [24] investigated the performance of a scroll expander in a small-scale ORC system through experimental testing. The scroll expander modified from a scroll compressor operated stably in the built ORC testing bench, and was tested under different conditions with various electric loads. The electric loads were adjusted by changing the number of the bulbs connected to the power generator. Five electric loads were adopted, that is, turning on 2 bulbs, 4 bulbs, 6 bulbs, 8 bulbs and 12 bulbs, and a maximum output power of $1200 \mathrm{~W}$ was achieved with 12 bulbs. It is also found the isentropic efficiency of the scroll expander increases with the electric load. 
In addition, Tang et al. [25] conducted an experimental testing of a low-grade heat ORC power generation system using a scroll expander with working fluid R600a, and found that the generator power output increases with the decrease of the load resistance at the same rotation speed. They also pointed out that electrical loads should match with the expandergenerator power output characteristics to get the optimal performance.

Although the number of published experimental studies on scroll-based ORC is on rise, most of scroll expanders were modified from refrigerating compressors. Wang et al. [26] found a maximum expander isentropic efficiency of $77 \%$ and power output of $1 \mathrm{~kW}$ from a scroll expander modified from a compliant scroll compressor using R134 as working fluid. More precisely, it is important to determine some operating parameters for achieving the system maximum energy efficiency; these parameters include pressure ratio, inlet condition and electrical load applied to ORC system. Therefore the effects of electrical resistive load on the performance of the ORC system with a small-scale scroll expander-generator unit are investigated experimentally in this paper; six different resistive loads are tested. The influences of electrical resistive load on electrical power output and scroll expander efficiencies are clarified under the same inlet condition.

\section{Experimental System}

A schematic diagram of the ORC system with instrumentation is shown in Fig.1 (a). A smallscale scroll expander-generator unit is employed in the system, which consists of an oil-free type of scroll expander and a separated electrical generator. An electric steam boiler is used as a low-temperature heat source in the system, and its temperature and mass flow rate could be adjusted. R134a is selected as the working fluid and heated to be high-pressure vapour in an evaporator by the steam from the boiler. The high-pressure vapour of R134a flows into the 
scroll expander, where its enthalpy is converted into shaft work to drive the generator for electricity generation. Then the low pressure vapour from the expander outlet flows through a regenerator to preheat the liquid working fluid from a storage tank, afterwards the low pressure vapour flows into a condenser for condensation, then the liquefied working fluid flows into the storage tank. Finally the liquid working fluid in the storage tank is pumped into the evaporator at high pressure to start the next cycle. Cold water is employed to condensate the low pressure vapour in the condenser and the steam in a cooler. The Pressure-Enthalpy $(P-h)$ diagram of the ORC system is shown in Fig. 1(b). A vapour by-pass line is installed to completely isolate the expander for the starting period and some emergency cases. Various operation conditions can be achieved by the valves V1-V7 for the system. The liquid working fluid pump is controlled by a frequency adaptor.

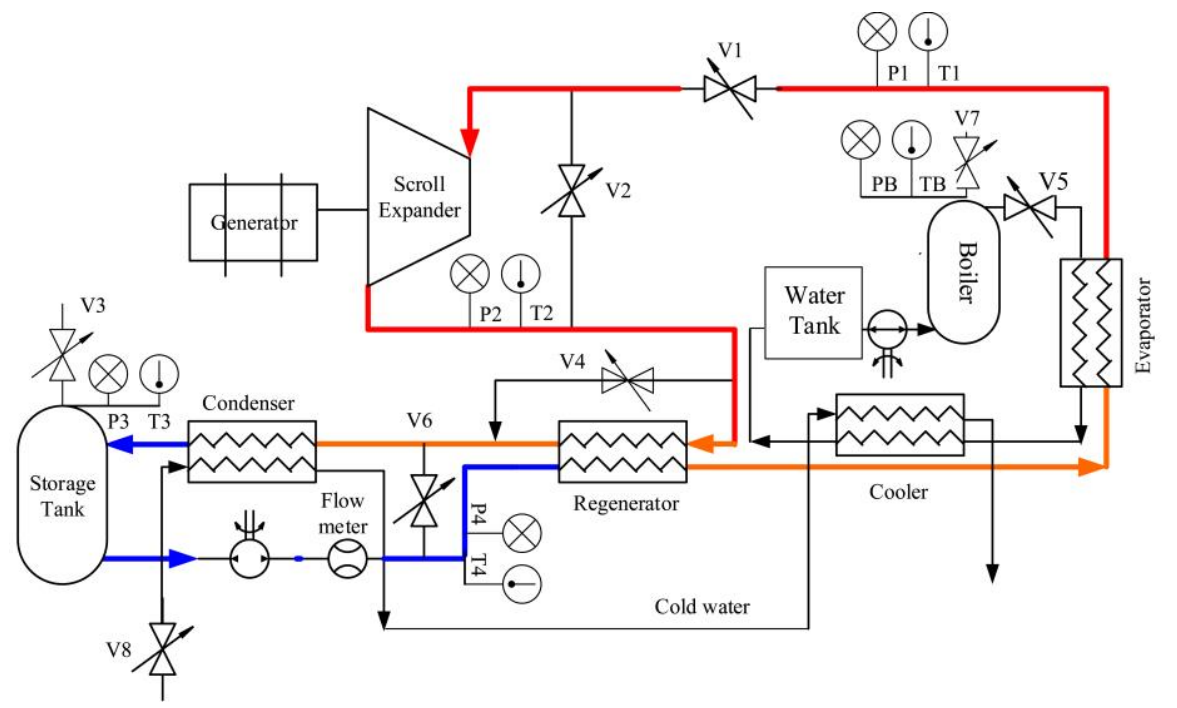

(a) Schematic graph of ORC with a scroll expander test rig 


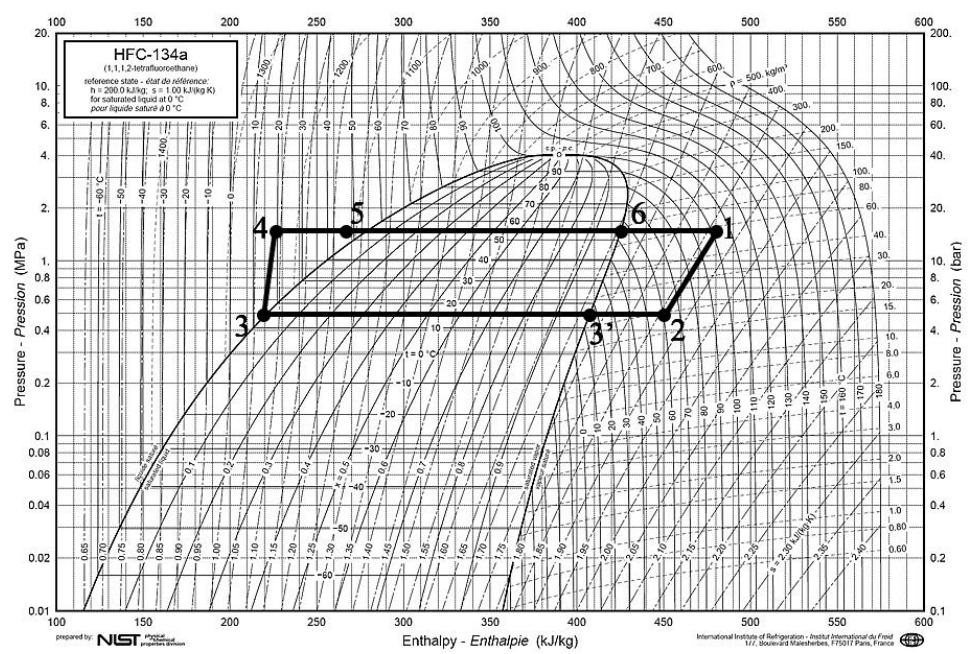

(b) $P$ - $h$ diagram of the ORC system

Fig. 1. Schematic diagram of ORC system and its $P$ - $h$ diagram

Based on the schematic diagram shown in Fig. 1(a), an experimental test rig of the ORC system is built as shown in Fig. 2. The electrical generator is coupled directly to the scroll expander in the unit [27]. The specifications of main equipment are presented in Table 1, and the measuring devices accuracies are listed in Table 2. OMEGA PXM Series pressure transducers and K-type temperature sensors are installed. A liquid flow meter is used to record the flow rate of R134a and a data acquisition system is employed to record the system parameters during operation by a computer. The power output of electrical generator is determined by voltage and current using a Power Quality Analyser.

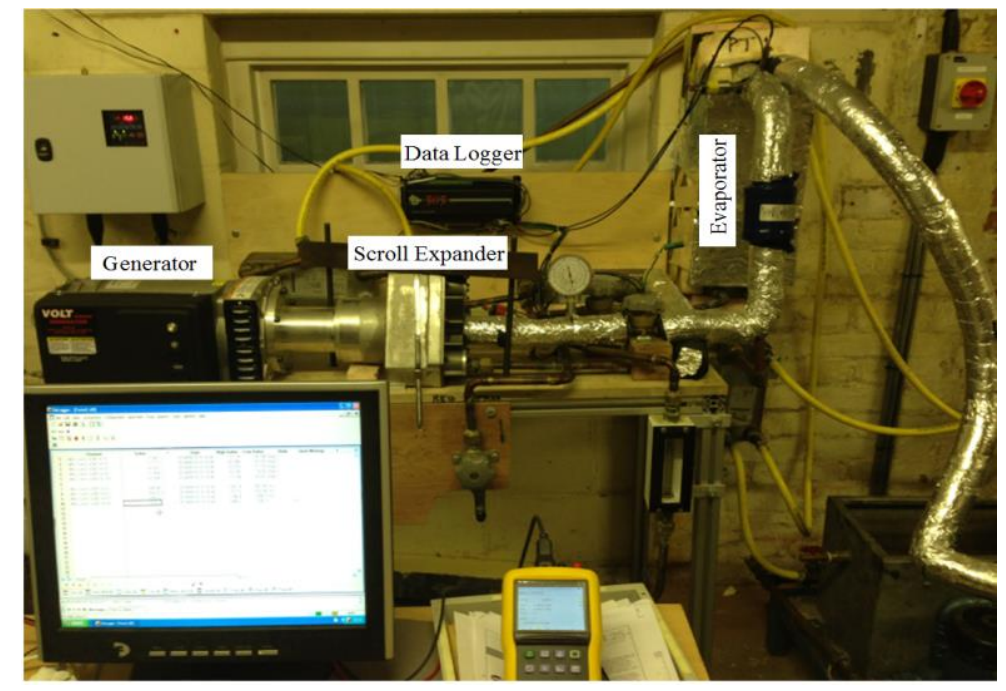

Fig. 2. Photo of the experimental test rig 
Table 1 Specifications of main equipment

\begin{tabular}{|c|c|c|c|}
\hline Equipment & \multicolumn{2}{|l|}{ Properties } & Manufacturer \\
\hline \multirow{2}{*}{$\begin{array}{l}\text { Electric Steam } \\
\text { Boiler }\end{array}$} & Rating Kilowatts & $24 \mathrm{~kW}$ & \multirow{2}{*}{$\begin{array}{l}\text { Fulton Boiler Works } \\
\text { (G.B.) Ltd. }\end{array}$} \\
\hline & Rated Output & $80 \mathrm{~kg} / \mathrm{hr}$ & \\
\hline \multirow{3}{*}{$\begin{array}{l}\text { Suction Line } \\
\text { Filter }\end{array}$} & Pressure & 27.5 bar & \multirow{3}{*}{$\begin{array}{l}\text { Emerson Alco Control } \\
\text { ASF-35S5 }\end{array}$} \\
\hline & Temperature Range & $-45^{\circ} \mathrm{C}-50^{\circ} \mathrm{C}$ & \\
\hline & Volume & 0.8 Litre & \\
\hline \multirow{5}{*}{$\begin{array}{l}\text { Evaporator } \\
\text { (equipment } \\
\text { capability) }\end{array}$} & Min. Temperature & $-196^{\circ} \mathrm{C}$ & \multirow{5}{*}{ SWEP B25T $\times 20$} \\
\hline & Max. Temperature & $225^{\circ} \mathrm{C}$ & \\
\hline & Test Pressure & 50 bar & \\
\hline & Heat Transfer Area & $7.6 \mathrm{~m}^{2}$ & \\
\hline & Max. Flow Rate & $12 \mathrm{~m}^{3} / \mathrm{h}$ & \\
\hline \multirow{9}{*}{$\begin{array}{l}\text { Scroll } \\
\text { Expander } \\
\text { (Oil Free) }\end{array}$} & Displacement & $12 \mathrm{~cm}^{3} / \mathrm{rev}$ & \multirow{9}{*}{$\begin{array}{l}\text { Air Squared } \\
\text { Manufacturing, Inc } \\
\text { E15H22N4.25 }\end{array}$} \\
\hline & Expansion Ratio & 3.5 & \\
\hline & Max pressure & 13.8 bar & \\
\hline & Max inlet temperature & $175^{\circ} \mathrm{C}$ & \\
\hline & Output & 1kW (nominal) & \\
\hline & Max rotation speed & $3600 \mathrm{r} / \mathrm{min}$ & \\
\hline & Standard ORC fluid & R-134a / R-245fa & \\
\hline & Lubrication & Oil-free & \\
\hline & Connection & Magnetic coupling & \\
\hline \multirow{5}{*}{$\begin{array}{l}\text { Electric } \\
\text { Generator }\end{array}$} & Rated Watts & $2400 \mathrm{~W}$ & \multirow{5}{*}{$\begin{array}{l}\text { Voltmaster Electric } \\
\text { Generator (AB30L) by } \\
\text { WANCO INC. }\end{array}$} \\
\hline & Rated AMPS & $20 \mathrm{~A}$ & \\
\hline & Rated Volts & $120 \mathrm{~V}$ & \\
\hline & Rated Hertz & $60 \mathrm{~Hz}$ & \\
\hline & Max. Ambient Temperature & $40^{\circ} \mathrm{C}$ & \\
\hline
\end{tabular}




\begin{tabular}{|c|c|c|c|}
\hline & Efficiency & $85 \%$ & \\
\hline \multirow{5}{*}{$\begin{array}{l}\text { Regenerator } \\
\text { (equipment } \\
\text { capability) }\end{array}$} & Min. Temperature & $-196^{\circ} \mathrm{C}$ & \multirow{5}{*}{$\begin{array}{l}\text { Brazed plate heat } \\
\text { exchangers SWEP } \\
\text { BX8TH×20 }\end{array}$} \\
\hline & Max. Temperature & $225^{\circ} \mathrm{C}$ & \\
\hline & Heat Transfer Area & $14 \mathrm{~m}^{2}$ & \\
\hline & & & \\
\hline & Max Flow Rate & $4 \mathrm{~m}^{3} / \mathrm{h}$ & \\
\hline \multirow{5}{*}{$\begin{array}{l}\text { Cooler } \\
\text { (equipment } \\
\text { capability) }\end{array}$} & Min. Working Temperature & $-160^{\circ} \mathrm{C}$ & \multirow{5}{*}{ SWEP B10H×30 } \\
\hline & Max. Temperature & $225^{\circ} \mathrm{C}$ & \\
\hline & Test Pressure & 50 bar & \\
\hline & Heat Transfer Area & $3.8 \mathrm{~m}^{2}$ & \\
\hline & Max Flow Rate & $12 \mathrm{~m}^{3} / \mathrm{h}$ & \\
\hline \multirow{5}{*}{$\begin{array}{l}\text { Magnetic } \\
\text { Pump }\end{array}$} & Maximum Speed & 5000RPM & \multirow{5}{*}{$\begin{array}{l}\text { Tuthill D Series Pump } \\
\text { (DXS2.3PPPT2NNSM } \\
\text { 257) }\end{array}$} \\
\hline & $\begin{array}{l}\text { Max Differential pressure } \\
\text { (intermittent) }\end{array}$ & $10.3 \mathrm{bar}$ & \\
\hline & $\begin{array}{l}\text { Max Differential pressure } \\
\text { (continuous) }\end{array}$ & 6.9 bar & \\
\hline & Max Temperature & $177^{\circ} \mathrm{C}$ & \\
\hline & Efficiency & $75 \%$ & \\
\hline Storage Tank & Max. Working Pressure & 10 bar & Zilmet S.p.A (092809) \\
\hline
\end{tabular}

Table 2 Measuring instrument accuracy

\begin{tabular}{|c|c|c|c|c|}
\hline Parameters & Instrument & Type & Measurement Range & Accuracy \\
\hline Pressure & $\begin{array}{l}\text { Pressure } \\
\text { transducer }\end{array}$ & $\begin{array}{l}\text { OMEGA } \\
\text { PXM41MD0- } \\
\text { 040BARGI }\end{array}$ & $0-40$ bar $\mathrm{G}$ & $0.25 \%$ \\
\hline Temperature & Thermocouple & $\begin{array}{l}\text { Type K insulated } \\
\text { thermocouple }\end{array}$ & $0-1100^{\circ} \mathrm{C}$ & $\pm 0.75 \%$ \\
\hline
\end{tabular}




\begin{tabular}{|c|c|c|c|c|}
\hline Voltage & \multirow{3}{*}{$\begin{array}{l}\text { Power Quality } \\
\text { Analyser }\end{array}$} & \multirow{3}{*}{$\begin{array}{l}\text { Chauvin Arnoux } \\
\text { CA } 8230\end{array}$} & AC: $6 V_{\mathrm{RMS}}-600 \mathrm{~V}_{\mathrm{RMS}}$ & $\pm 0.5 \%$ \\
\hline Current & & & AC: $100 \mathrm{~mA}-6500 \mathrm{~A}$ & $\pm 0.5 \%$ \\
\hline Frequency & & & $40 \mathrm{~Hz}-70 \mathrm{~Hz}$ & $\pm 0.5 \%$ \\
\hline Flow rate & Flow meter & $\begin{array}{l}\text { Platon GU Glass } \\
\text { Tube VA } \\
\text { Flowmeter }\end{array}$ & $0.05-1.4 \mathrm{~L} / \mathrm{min}$ & $\pm 1.25 \%$ \\
\hline $\begin{array}{l}\text { Data } \\
\text { Acquisition }\end{array}$ & Data Logger & DataTaker 505 & - & $0.15 \%$ \\
\hline
\end{tabular}

Once the steady-state regime of operation is reached, a complete measurement data set is produced. These experimental data include pressure, temperature, working fluid flow rate, and electrical load voltage and current. Subsequently, those data are processed to determine the isentropic and volumetric efficiencies of the scroll expander and electrical efficiencies of the ORC system.

\section{Thermodynamic Model}

Referring to the Pressure-Enthalpy diagram of the ORC system in Fig. 1(b), a thermodynamic model is developed to analyse the system performance. The components of the ORC system are considered as steady state flow devices, the kinetic and potential energies are neglected. The working fluid R134a is heated in the evaporator $(4 \rightarrow 5 \rightarrow 6 \rightarrow 1)$ in which heat is transferred from the heat source (boiler) to the working fluid. The thermal load $\left(Q_{i n}\right)$ supplied by the boiler via the evaporator is defined as

$$
Q_{\text {in }}=m_{f}\left(h_{1}-h_{4}\right)(\mathrm{kW})
$$

Where $m_{f}$ is the working fluid mass flow rate $(\mathrm{kg} / \mathrm{s})$ and $h$ is the specific enthalpy of the working fluid $(\mathrm{kJ} / \mathrm{kg})$. 
Both the desuperheated process $\left(2 \rightarrow 3^{\prime}\right)$ and the preheated process $(4 \rightarrow 5)$ occur in the regenerator. The recovered heat $\left(Q_{r}\right)$ in the regenerator is:

$$
Q_{r}=m_{f}\left(h_{2}-h_{3^{\prime}}\right)=m_{f}\left(h_{5}-h_{4}\right)(\mathrm{kW})
$$

Taken the recovery heat from the regenerator into consideration, the equation (1) relating to the heat input will be changed as:

$$
Q_{i n}=m_{f}\left(h_{1}-h_{5}\right)(\mathrm{kW})
$$

The input power of the liquid working fluid pump $\left(P_{p}\right)(3 \rightarrow 4)$, which is defined as

$$
P_{p}=m_{f}\left(h_{4}-h_{3}\right)(\mathrm{kW})
$$

Where the specific enthalpy of state $4\left(h_{4}\right)$ is correlated with the pump efficiency $\eta_{p}$.

The work done by the scroll expander $\left(P_{s}\right)$ in the expansion process $(1 \rightarrow 2)$ is given by

$$
P_{s}=m_{f}\left(h_{1}-h_{2}\right) \eta_{v} \eta_{m}(\mathrm{~kW})
$$

Where $\eta_{v}$ is the volumetric efficiency of the scroll expander which is defined in Eq. (11), and $\eta_{m}$ is the scroll expander mechanical efficiency.

As heat input and power output are the main parameters to indicate the system energy conversion efficiency, the net electrical power output $\left(P_{e}\right)$ produced by the ORC system with neglecting the little work consumed by liquid pump is defined as

$$
P_{e}=P_{s} \cdot \eta_{g}(\mathrm{~kW})
$$

Where $\eta_{g}$ is the generator efficiency.

Hence, the ORC system electrical efficiency $\left(\eta_{e g}\right)$ is defined as the ratio between the electrical power output and the heat rate absorbed by the fluid in the evaporator:

$$
\eta_{e g}=\frac{P_{e}}{Q_{i n}}
$$


The performance of the scroll expander can be assessed by its isentropic, volumetric and mechanical efficiencies. The isentropic efficiency of the scroll expander $\left(\eta_{i s}\right)$ is defined as the ratio of the actual enthalpy drop to the isentropic enthalpy drop in the expansion process.

$$
\eta_{i s}=\frac{h_{1}-h_{2}}{h_{1}-h_{2 s}}
$$

Where $h_{2 s}$ is the specific enthalpy of state 2 in isentropic expansion process $(\mathrm{kJ} / \mathrm{kg})$.

The ideal volumetric flow rate at the scroll expander inlet state can be calculated as:

$$
V_{i, \text { ideal }}=V_{\text {in }} \times \frac{n}{60}\left(\mathrm{~m}^{3} / \mathrm{s}\right)
$$

Where $n$ represents the rotation speed of the scroll expander (r/min) and $V_{\text {in }}$ is the volume of the scroll expander $\left(\mathrm{m}^{3}\right)$. However, the actual volumetric flow rate at the expander inlet state is larger than the ideal volumetric flow rate due to the internal leakage of scroll expander, which can be expressed as

$$
V_{i}=m_{f} v_{i}\left(\mathrm{~m}^{3} / \mathrm{s}\right)
$$

Where $v_{i}$ is the specific volume of the vapour at the expander inlet condition $\left(\mathrm{m}^{3} / \mathrm{kg}\right)$. Therefore, the volumetric efficiency of the scroll expander $\left(\eta_{v}\right)$ is defined as

$$
\eta_{v}=\frac{V_{i, \text { ideal }}}{V_{i}}=\frac{V_{i n} \times \frac{n}{60}}{m_{f} v_{i}}
$$

By taking the performance of the scroll expander into account, the electrical efficiency of ORC system can be summarized as a function of the scroll expander isentropic, volumetric and mechanical efficiencies, and generator efficiency.

$$
\eta_{e g}=\eta_{v} \eta_{i s} \eta_{m} \eta_{g} \frac{\left(h_{1}-h_{2 s}\right)}{\left(h_{1}-h_{5}\right)}
$$




\section{Experimental Results and Discussions}

A series of tests are performed with the ORC test rig to evaluate the performance of the ORC system. The generator is coupled directly to the scroll expander, so it rotates at the same speed as the scroll expander. To study the effects of electrical load applied to the ORC system, six different resistive consumers are selected for load simulation, which are 18.6 $\Omega$, $19.4 \Omega, 26.2 \Omega, 34.7 \Omega, 64.0 \Omega$ and $75.6 \Omega$ respectively.

Error bars are included in the experimental result analysis, which are associated with the calculated uncertainties. The measuring instrument uncertainties are obtained from the device datasheets. The calculated parameter uncertainty $U_{y}$ is given by Eq. (13) [28]:

$$
U_{y}=\sqrt{\sum_{i=1}^{N}\left(\frac{\partial y}{\partial x_{i}}\right)^{2} \cdot U_{x_{i}}{ }^{2}}
$$

Where $U_{x i}$ is the uncertainty of each measured variable $x_{i}$.

\subsection{Variation of electrical power output with resistive load}

The resistive load coupled to the scroll expander-generator unit results in shaft resisting torque. For a low resistive load, the generated current is high, based on the interaction between electromagnetic and mechanical loads, the corresponding shaft resisting torque is high owing to the proportional relation between the current and the torque. To ensure the scroll expander-generator unit runs smoothly, the shaft torque produced by the scroll expander should be equal to the total resisting torques induced by the generator and various fictions. The variations of power output at different rotation speeds (e.g. 3432, 3144, 3006, $2730 \mathrm{r} / \mathrm{min}$ ) are presented in Fig. 3. As can be seen, the power output decreases with resistive load under a fixed rotation speed. However, the decreasing rate of power output declines gradually as the resistive load gets higher. When the scroll expander rotates at a speed of $3432 \mathrm{r} / \mathrm{min}$, the output power is $557.2 \mathrm{~W}$ for a resistive load of $18.6 \Omega$, while only $20 \%$ of the 
power is generated for a resistance of $75.6 \Omega$. Moreover, the linear relationship between the power output and rotation speed is clearly indicated for all resistive loads. The increasing rate for the lower resistive load is much higher than that for the higher one. As the expander rotation speed rises from $2730 \mathrm{r} / \mathrm{min}$ to $3432 \mathrm{r} / \mathrm{min}, 257.7 \mathrm{~W}$ more power can be produced for resistive load of $18.6 \Omega$, while the power output increase is only $68.5 \mathrm{~W}$ for the resistance of

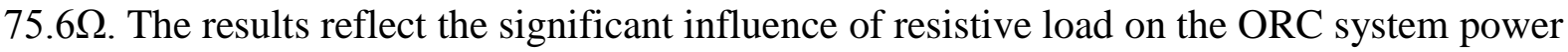
output. The experimental study of a small ORC power generation system with five different load resistances $(20 \Omega, 60 \Omega, 100 \Omega, 140 \Omega$ and $180 \Omega)$ is presented in the literature [25]. The experimental system was built using a scroll expander with the working fluid R600a. The scroll expander maximum rotation speed is $2922 \mathrm{r} / \mathrm{min}$ and its expansion ratio is 3.03 . The measurement data also confirms the decreasing rate of power output with the resistive load becomes larger at high rotation speed, but the rate is different from this study's owing to the different working fluids and operating conditions.

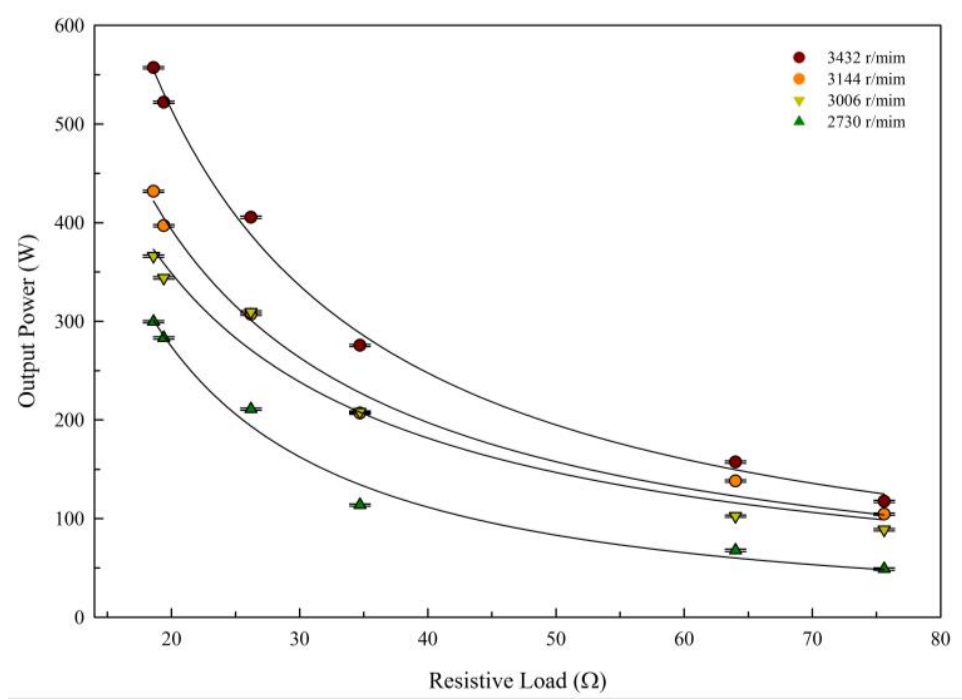

Fig. 3. Variations of electrical power output at 3432, 3144, 3006, $2730 \mathrm{r} / \mathrm{min}$ 


\subsection{Variation of electrical power output with pressure ratio}

The pressure ratio of the scroll expander is defined as the inlet pressure divided by the outlet pressure. As the evaporation and condensation pressures of the working fluid are influenced by the temperatures of heat source and heat sink separately, the pressure ratio of the expander could be controlled correspondingly. The variations of the power output with the pressure ratio for the six different resistive configurations are shown in Fig. 4 (a). For a certain resistive load, the power output increases with the pressure ratio until reaching the maximum point and then drops down gradually. Moreover, it can be observed that the resistive load has impact on the optimal pressure ratio markedly from Fig. 4 (b). Initially, the optimal pressure ratio decreases sharply as the resistive load gets higher and then the decrease rate declines gradually. As the shaft torque correlates the power output, low power is produced with a requirement of low pressure ratio for the expander. The optimal pressure ratio for the resistive load of $18.6 \Omega$ is approximately 3.6 and the maximum power output is $564.5 \mathrm{~W}$, while only $154.2 \mathrm{~W}$ power is generated for the resistance of $64.0 \Omega$ under an optimal pressure ratio of 2.8. The relationship implies a low electrical resistive load contributes to the large amount of power output under the higher optimal pressure ratio.

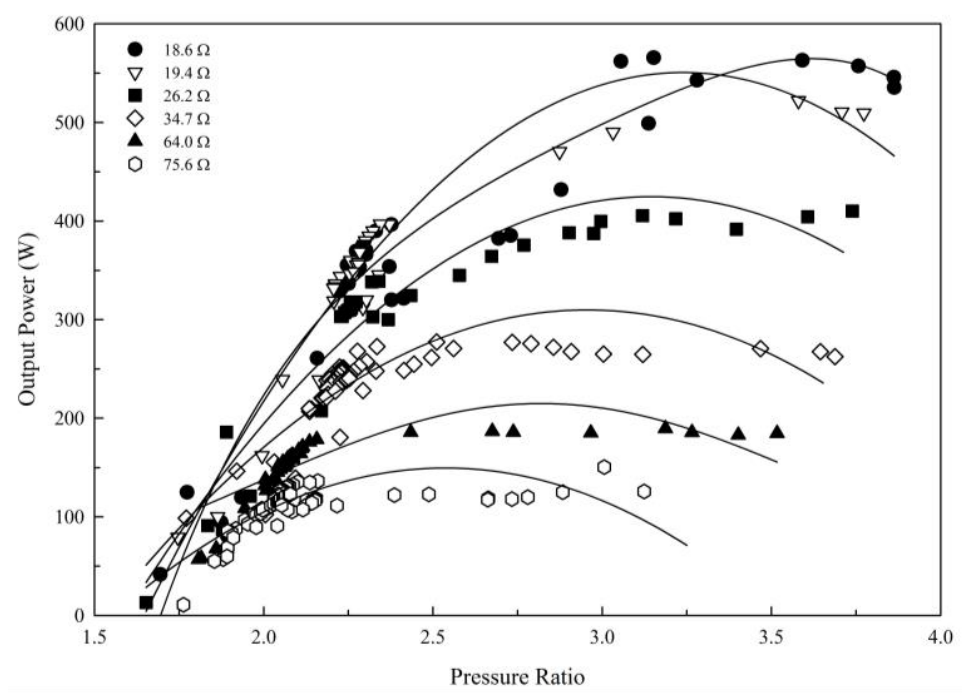

(a) 


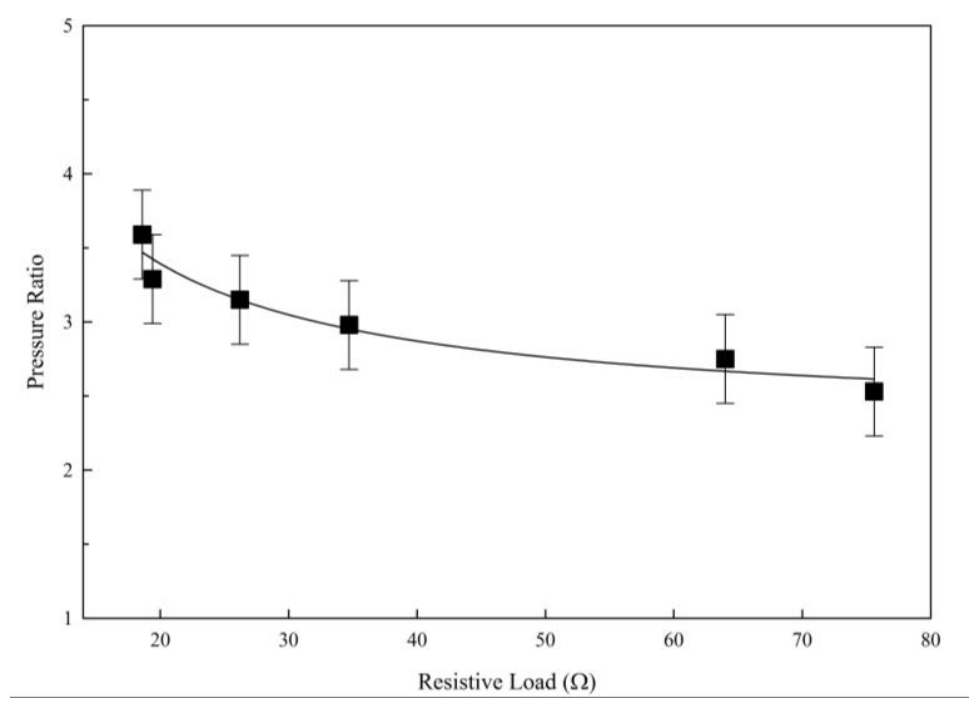

(b)

Fig. 4. Variations of (a) electrical power output with pressure ratio and (b) optimal pressure ratio with resistive load

\subsection{Variations of electrical power output with pressure ratio and rotation speed}

A set of 3-dimensional images is presented in Fig. 5 to show the variations of power output with scroll expander rotation speed and pressure ratio for all resistive loads. In particular, with a resistive load of $18.6 \Omega$, the power output increases dramatically with the pressure ratio and rotation speed, and reaches the maximum point $(564.5 \mathrm{~W})$ under a pressure ratio of 3.6 and a rotation speed of $3450 \mathrm{r} / \mathrm{min}$, and then the output power decreases as the pressure ratio gets bigger than 3.6 and the scroll expander rotates faster. Therefore, the load characteristic in correlation to the expander-generator unit plays an important role in achieving an optimal performance for an ORC system. 

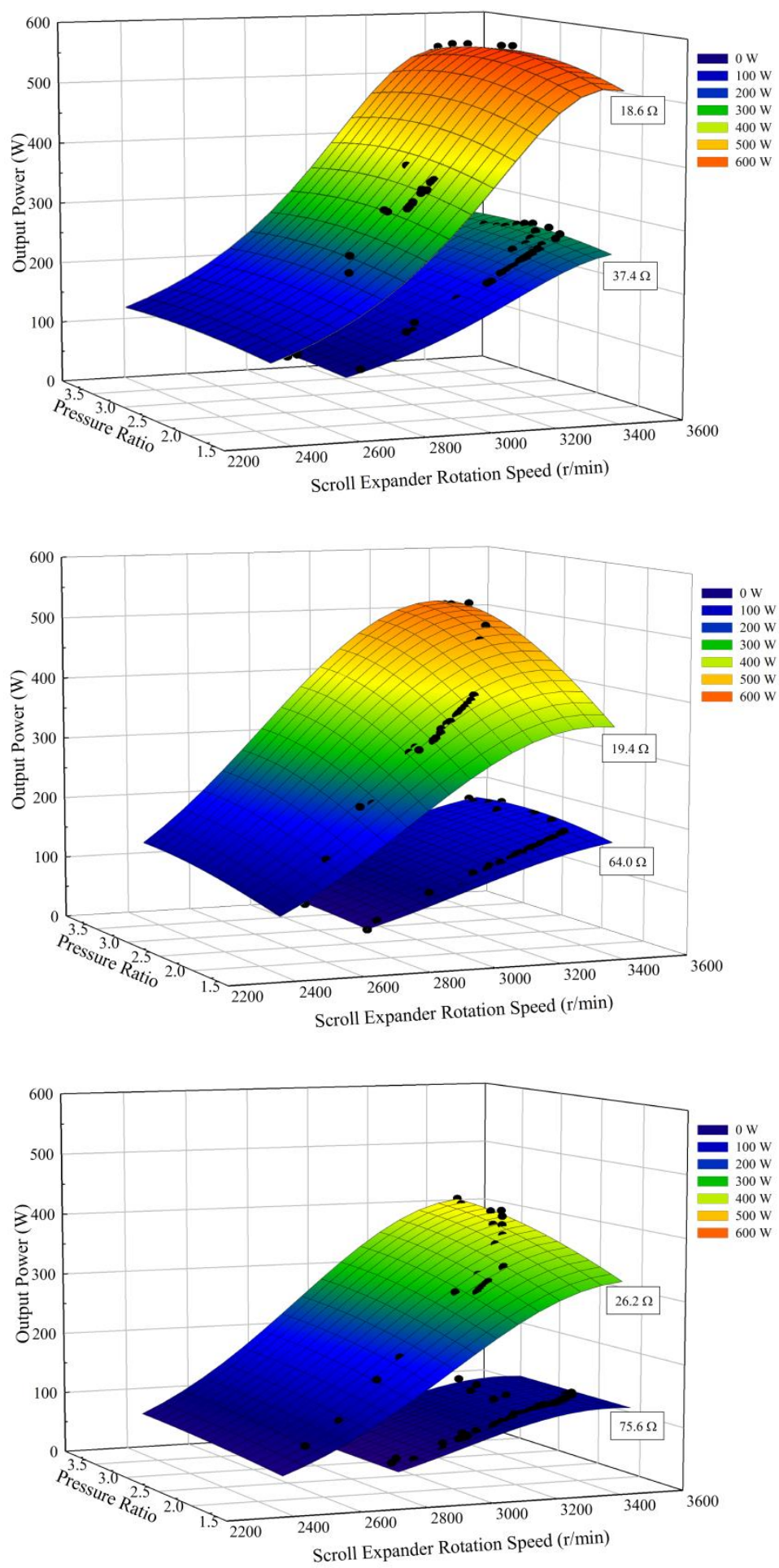

Fig. 5. Variations of electrical power output with pressure ratio and rotation speed 


\subsection{Variations of electrical efficiency and scroll expander efficiency with resistive load}

The maximum electrical efficiency under the optimal pressure ratio for each resistive load is presented in Fig. 6 (a). A dramatically decreasing trend can be observed for the electrical efficiency curve, which is similar to that of the power output in Fig. 4(b). The maximum electrical efficiency reaches $2.04 \%$ for the resistive load of $18.6 \Omega$; however it drops by $70 \%$ for the resistance of $64.0 \Omega$.

Referring to Equation (12), the electrical efficiency of the ORC system relates to the performance characteristics of the scroll expander. To evaluate the effects of resistive load on scroll expander isentropic and volumetric efficiencies, the investigation is carried out under the optimal pressure ratio operating condition for the six resistive loads. Different resistive loads result in different resisting torques, which hence influence the operation of the scroll expander simultaneously as shown in Fig. 6 (b). The graph clearly shows that the lower resistive load results in both higher isentropic and volumetric efficiencies. Compared with the decreasing rate of isentropic efficiency, the effect of resistive load on the volumetric efficiency is more significant. For the resistive load of $18.6 \Omega$, the isentropic and volumetric efficiencies are $78 \%$ and $83 \%$ respectively while the isentropic efficiency reduces to $65 \%$ and the volumetric efficiency decreases by $41.7 \%$ for a higher resistive load of $75.6 \Omega$. The variation of scroll expander isentropic efficiency with the resistive load has the same trend as that in the literature [24]. For example, the isentropic efficiencies are $78 \%$ for the resistive load of $18.6 \Omega$ and $70 \%$ for the resistive load of $34.7 \Omega$ in this study, the efficiency decreases $8 \%$ as the resistive load nearly doubles. The electric loads in the literature [24] were adjusted by changing the number of the bulbs parallel connected to the power generator, the isentropic efficiencies are $55 \%$ for 12 bulbs and $47 \%$ for 6 bulbs, so the isentropic efficiency also decreases $8 \%$ when the resistive load doubles. 


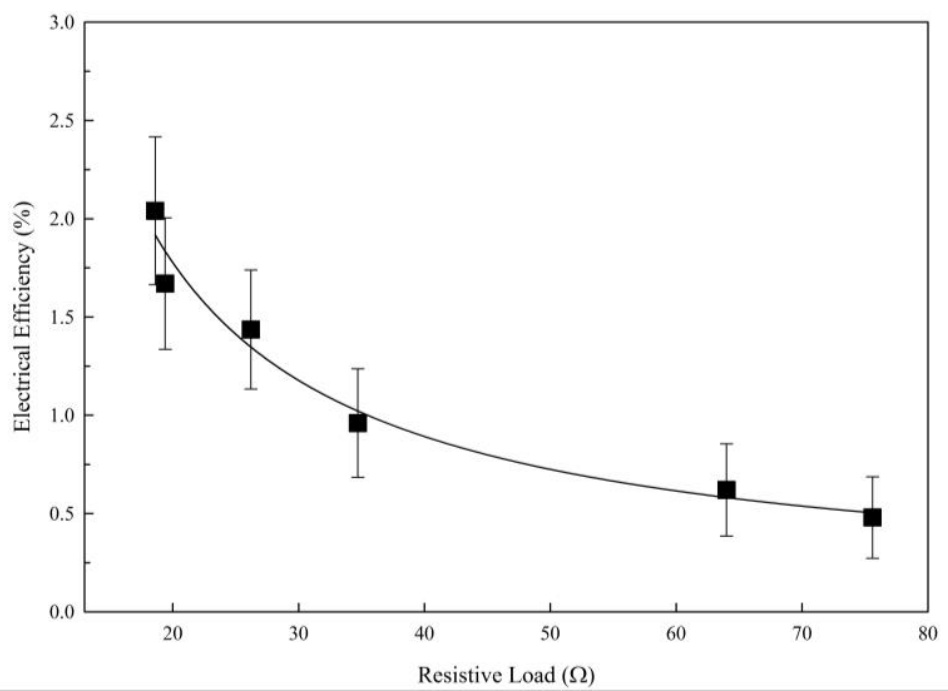

(a)

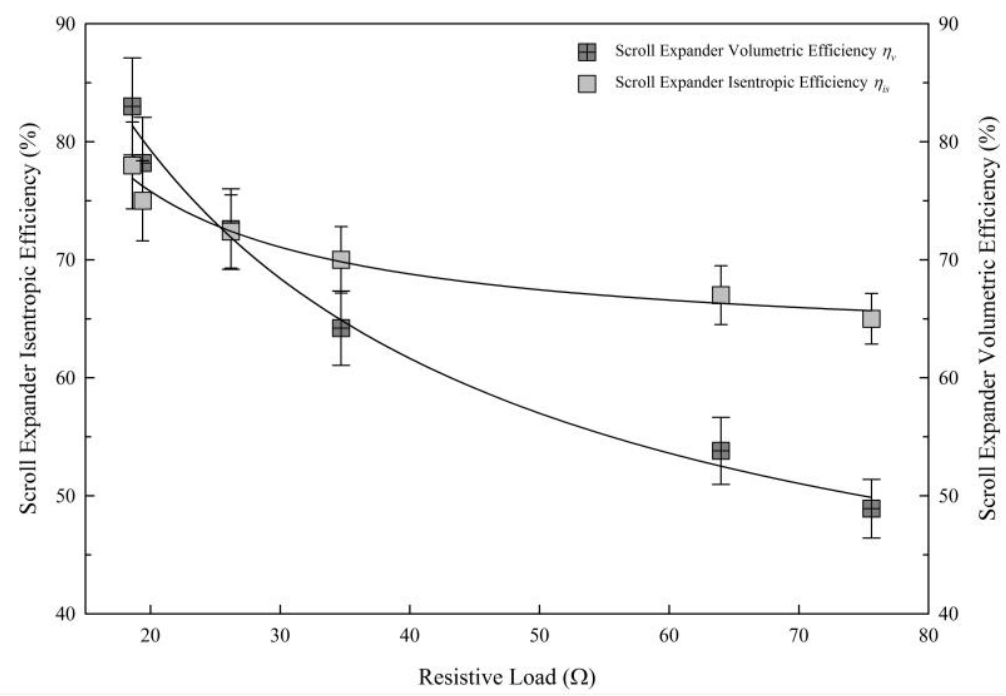

(b)

Fig. 6. Variations of (a) electrical efficiency and (b) isentropic and volumetric efficiencies under optimal pressure ratio condition

\section{Conclusions}

A test rig of an ORC system with a small-scale scroll expander-generator unit is developed to investigate resistive load effects under the same scroll expander inlet condition; some important conclusions are drawn as following. 
1) Different resistive loads coupled to the scroll expander-generator unit result in different shaft resisting torques. The low resistive load leads to the high linear increase rate in power output with the rotation speed. The power output decreases with resistive load at a fixed rotation speed, and the decreasing rate of power output reduces gradually.

2) There exists an optimal pressure ratio with the maximum output power for each electrical resistive load. The optimal pressure ratio decreases markedly with the resistive load.

3) The optimal pressure ratio at a corresponding rotation speed can be determined from the variations of power output with pressure ratio and rotation speed. For a resistive load of $18.6 \Omega$, the optimal pressure ratio is 3.6 with the maximum output power of $564.5 \mathrm{~W}$ at a rotation speed of $3450 \mathrm{r} / \mathrm{min}$.

4) The electrical efficiency decreases significantly with resistive load. The maximum electrical efficiency drops by $70 \%$ for the resistance of $64.0 \Omega$ compared with a load of 18.6 $\Omega$. The lower resistive load results in both higher isentropic and volumetric efficiencies of scroll expander. The expander volumetric efficiency drops by $41.7 \%$ as the resistive load increases from $18.6 \Omega$ to $75.6 \Omega$, while the isentropic efficiency reduces from $78 \%$ to $65 \%$.

\section{Acknowledgments:}

The authors thank to EU SEVENTH FRAMEWORK PROGRAMM-Marie Curie Actions (FP7-PEOPLE-2011-IIF, 298340) for the project support. 


\section{Nomenclature}

$h \quad$ Specific enthalpy of working fluid $(\mathrm{kJ} / \mathrm{kg})$

$m_{f} \quad$ Working fluid mass flow rate $(\mathrm{kg} / \mathrm{s})$

$n \quad$ Rotation speed ( $\mathrm{r} / \mathrm{min})$

$P_{e} \quad$ Net electrical power output of ORC system (kW)

$P_{p} \quad$ Input power of liquid pump $(\mathrm{kW})$

$P_{s} \quad$ Work output of scroll expander $(\mathrm{kW})$

$Q_{\text {in }} \quad$ Input heat $(\mathrm{kW})$

$Q_{r} \quad$ Recovered heat $(\mathrm{kW})$

$U_{x} \quad$ Measured variable uncertainty

$U_{y} \quad$ Calculated parameter uncertainty

$V_{i, \text { ideal }}$ Ideal volumetric flow rate at expander inlet state $\left(\mathrm{m}^{3} / \mathrm{s}\right)$

$V_{i} \quad$ Actual volumetric flow rate at expander inlet state $\left(\mathrm{m}^{3} / \mathrm{s}\right)$

$v_{i} \quad$ Specific volume of vapour at expander inlet state $\left(\mathrm{m}^{3} / \mathrm{kg}\right)$

$V_{\text {in }} \quad$ Scroll expander volume $\left(\mathrm{m}^{3}\right)$

Greek letters

$\eta_{e g} \quad$ Electrical efficiency of ORC system

$\eta_{g} \quad$ Generator efficiency

$\eta_{i s} \quad$ Scroll expander isentropic efficiency

$\eta_{m} \quad$ Scroll expander mechanical efficiency

$\eta_{p} \quad$ Pump efficiency

$\eta_{v} \quad$ Scroll expander volumetric efficiency 


\section{References:}

1. Quoilin S, Broek MVD, Declaye S, Dewallef P, Lemort V. Techno-economic survey of Organic Rankine Cycle (ORC) systems. Techno-economic survey of Organic Rankine Cycle (ORC) systems 2013; 22: 168-186.

2. Drescher U, Brüggemann D. Fluid selection for the Organic Rankine Cycle (ORC) in biomass power and heat plants. Applied Thermal Engineering 2007; 27(1): 223-228.

3. Kane M. Small hybrid solar power system. Energy 2003; 28(14): 1427-1443.

4. Zhu J, Huang HL. Performance analysis of a cascaded solar Organic Rankine Cycle with superheating. International Journal of Low-Carbon Technologies 2014; 0: 1-8.

5. Badr O, O'Callaghan PW, Probert SD. Thermodynamic and thermophysical properties of organic working fluids for Rankine-cycle engines. Applied Energy 1985; 19: 1-40.

6. Saleh B, Koglbauer G, Wendland M, Fischer J. Working fluids for low temperature organic Rankine cycles. Energy 2007; 32: 1210-1221.

7. Li G. Organic Rankine cycle performance evaluation and thermoeconomic assessment with various applications part I: energy and exergy performance evaluation. Renewable and Sustainable Energy Reviews 2016; 53: 477-499.

8. Aghahosseini S, Dincer I. Comparative performance analysis of low-temperature Organic Rankine Cycle (ORC) using pure and zeotropic working fluids. Applied Thermal Engineering 2013; 54: 35-42.

9. Declaye S, Quoilin S, Lemort V. Design and Experimental Investigation of a Small Scale Organic Rankine Cycle Using a Scroll Expander. Proceedings of the $20^{\text {th }}$ International refrigeration and air conditioning conference at Purdue 2010; 2512: 1-7.

10. Tchanche BF, Papadakis G, Lambrinos G, Frangoudakis A. Fluid selection for a lowtemperature solar organic Rankine cycle. Applied Thermal Engineering 2009; 29(11-12): 2468-2476. 
11. Qiu G, Liu H, Riffat S. Expanders for micro-CHP systems with organic Rankine cycle. Applied Thermal Engineering 2011; 31(16): 3301-3307.

12. Ali Tarique M, Dincer I, Zamfirescu C. Experimental investigation of a scroll expander for an organic Rankine cycle. International Journal of Energy Research 2014; 38(14): $1825-1834$.

13. Peterson R, Herron $\mathrm{T}$, Wang $\mathrm{H}$. Performance of a small-scale regenerative Rankine power cycle employing a scroll expander. Proceedings of the Institution of Mechanical Engineers, Part A: Journal of Power and Energy 2008; 222(3): 271-282.

14. Lemort V, Declaye S, Quoilin S. Experimental characterization of a hermetic scroll expander for use in a micro-scale Rankine cycle. Proceedings of the Institution of Mechanical Engineers, Part A: Journal of Power and Energy 2011; 226: 126-136.

15. Wang HL, Peterson R, Harada K, Miller E, Ingram-Goble R, Fisher L, Yih J, Ward C. Performance of a combined organic Rankine cycle and vapour compression cycle for heat activated cooling. Energy 2011; 36(1): 447-458.

16. Harada K. Development of a Small Scale Scroll Expander. Master Thesis in Mechanical Engineering 2010, Oregon State University.

17. Zhang S, Wang H, Guo T. Performance comparison and parametric optimization of subcritical Organic Rankine Cycle (ORC) and transcritical power cycle system for lowtemperature geothermal power generation. Applied Energy 2011; 88: 2740 - 2754.

18. Hogerwaard J, Dincer I, Zamfirescu C. Analysis and assessment of a new organic Rankine cycle system with/without cogeneration. The International Journal of Energy 2013; 62: 300-310.

19. Declaye S, Quoilin S, Guillaume L, Lemort V. Experimental study on an open-drive scroll expander integrated into an ORC (Organic Rankine Cycle) system with R245fa as working fluid. Energy 2013; 55: 173-183. 
20. Antonio Giuffrida. Modelling the performance of a scroll expander for small organic Rankine cycles when changing the working fluid. Applied Thermal Engineering 2014; 70: $1040-1049$.

21. Clemente S, Micheli D, Reini M, Taccani R. Energy efficiency analysis of Organic Rankine Cycles with scroll expanders for cogenerative applications. Applied Energy 2012; 97: 792-801.

22. Mago PJ, Chamra LM, Srinivasan K, Somayaji C. An examination of regenerative organic Rankine cycles using dry fluids. Applied Thermal Engineering 2008; 28(8-9): 998-1007.

23. Pan D, Wang YP, Yang P, Weng YW. Experimental research on the performance of scroll expander used in organic Rankine cycle. Fluid Machinery 2014; 42(5): 10-14.

24. Wu Z, Pan D, Gao N, Zhu T, Xie F. Experimental testing and numerical simulation of scroll expander in a small scale organic Rankine cycle system. Applied Thermal Engineering 2015; 87: 529-537.

25. Tang L, Gao NP, Xie FB, An W, Wang HY, Wang H, Zhu T. Experimental study of optimal load characteristics of low temperature heat organic Rankine cycle power generation. Journal of Shanghai Jiao Tong University 2014; 48(9): 1268-1273.

26. Wang H, Peterson RB, Herron T. Experimental performance of a compliant scroll expander for an organic Rankine cycle. Proceedings of the Institution of Mechanical Engineers, Part A: Journal of Power and Energy 2009; 223(7): 863-872.

27. Scroll Expander, E15H22N4.25. Air Squared Manufacturing, Inc. http://airsquared.com.

28. Lemort V, Quoilin S, Cuevas C, Lebrum J. Testing and modelling a scroll expander integrated into an Organic Rankine Cycle. Applied Thermal Engineering 2009; 29(1415): 3094-3102. 